\title{
Diel and seasonal variations in bacterioplankton production in a hypertrophic shallow lagoon
}

\author{
Gabriela Onandia*, Maria Rosa Miracle, Cristina Blasco, Eduardo Vicente \\ Department of Microbiology and Ecology, ICBiBE, University of Valencia, Calle Dr. Moliner 50, 46100 Burjassot, \\ Valencia, Spain
}

\begin{abstract}
Diel and seasonal variations in bacterial secondary production (BP) were investigated in the hypertrophic Albufera de Valencia (Spain) by measuring ${ }^{3} \mathrm{H}$-leucine and ${ }^{3} \mathrm{H}$-thymidine incorporation rates (LIR and TIR). LIR and TIR were positively correlated. Seasonal variations in the LIR:TIR ratio seemed to be related to dissolved organic carbon (DOC) availability, with higher concentrations favoring protein synthesis. The light:dark ratio of the incorporation rates of both radiotracers was close to 1 . However, this ratio tended to be $>1$ when DOC was lower, namely in winter. A clear diel pattern in bacterial activity was found, with an increasing trend during the night hours. The opposite diel pattern was observed for DOC. BP remained similar across seasons but showed a decrease in late winter during a period of high water discharge through the lagoon and concurrent minimum chlorophyll a concentrations. A comparison between hypertrophic systems aiming to explore the upper BP limit indicated that our BP estimates were considerably high but did not surpass previous values in hypertrophic lakes.
\end{abstract}

KEY WORDS: Bacterioplankton production · Carbon flux · Shallow hypertrophic lake

\section{INTRODUCTION}

Heterotrophic bacterioplankton play a major role in the carbon flux and nutrient cycling of aquatic food webs (Azam et al. 1983). They are the main decomposers of organic matter and provide a link among particulate detritus, dissolved organic matter, and higher trophic levels (Cole et al. 1988). Bacterial secondary production (BP) has been widely studied across aquatic systems, but there is limited information about whether the existence of diel cycles depends on the ecosystem trophic state. The dissolved organic carbon (DOC) released by primary producers constitutes an important energy source for heterotrophic bacteria (Baines \& Pace 1991). Given the light-driven diel variations in phytoplankton production, the amount of photosynthetic release available for heterotrophic bacteria likely fluctuates during the day, thereby causing diel variations in BP. Various studies have described the occurrence of diel cycles in oligotrophic waters (e.g. Kuipers et al. 2000, Winter et al. 2004), where the linkage between autochthonous DOC and bacterioplankton is clear. However, no diurnal variations were found in mesotrophic shallow lakes in a study by Petrucio \& Barbosa (2004), and similarly, no evident diel pattern appears to exist in eutrophic waters (Riemann \& Søndergaard 1984). The significant subsidies of allochthonous material may be one plausible explanation for our inability to distinguish the impact of autochthonous DOC on the occurrence of diel cycles in productive waters (Gasol et al. 1998). Even more profound gaps in our knowledge exist in regard to the daily variations, the seasonal patterns, and the general contribution of BP production in shallow hypertrophic 'hypereutrophic' lakes (Sommaruga \& Robarts 1997, Auer et al. 2004, Tammert et al. 2005), which typically represent the final stage of eutrophication. 
From a methodological standpoint, an additional controversial issue related to the causal association between light availability for bacteria and BP is the appropriateness of measurements obtained under dark conditions. The importance of measuring BP in the light has been emphasized in numerous studies (e.g. Aas et al. 1996, Morán et al. 2001). More recently, the use of parallel incubations under light and dark conditions when measuring BP was strongly recommended (Gasol et al. 2008). Further, the high diversity of sunlight effects on leucine and thymidine bacterial incorporation rates reported in the literature questions the earlier assumed detrimental influence of light (RuizGonzález et al. 2013), and yet studies involving light incubations are scarce, especially in freshwater ecosystems.

The hypertrophic Albufera de Valencia lagoon (Spain) was selected to study the aforementioned issues. This shallow lagoon located on the Mediterranean coast shifted from a clear to a turbid state as a consequence of intense eutrophication processes that started in the 1960s, and resulted in the loss of the macrophyte cover (Vicente \& Miracle 1992, Romo et al. 2005). In its present state, the lagoon is hypertrophic, with a phytoplankton community dominated by cyanobacteria. However, short 'clearwater' events occasionally occur in the winter, as a result of the 'flushing' experienced by the lagoon during the draining of the surrounding flooded paddies. These events are characterized by a dramatic decrease in water turbidity and total phytoplankton biomass, a reduction in the relative contribution of cyanobacteria to the composition of the algal assemblages, and the growth of large cladocerans (Miracle \& Sahuquillo 2002, Romo et al. 2005). However, the response of heterotrophic bacteria to these events remains unstudied to this point.

The objectives of this work were mainly (1) to assess the seasonal BP variability and, more specifically, to examine how closely BP follows the variations in water turbidity, and (2) to test whether there is a clear diel pattern of bacterioplankton production in hypertrophic lakes. The effects of light/dark incubations on incorporation rates of ${ }^{3} \mathrm{H}$-leucine and ${ }^{3} \mathrm{H}$ thymidine by heterotrophic bacteria were also investigated. Additionally, our study aimed to shed light on the upper limit of BP in hypertrophic systems. In doing so, we address a major knowledge gap by providing insights into the dynamics and contribution of bacterioplankton to the carbon cycle in hypertrophic lakes.

\section{MATERIALS AND METHODS}

\section{Study site and experimental design}

Albufera de Valencia is a shallow, oligohaline (salinity $\approx 1 \%$ o) lagoon located on the Mediterranean coast, $15 \mathrm{~km}$ south of the town of Valencia (Spain). It covers an area of approximately $24 \mathrm{~km}^{2}$ and has a mean depth of about $1 \mathrm{~m}$. At present, Albufera de Valencia is a turbid lake dominated by phytoplankton, predominantly cyanobacteria (Vicente \& Miracle 1992, Romo et al. 2008). The lake is surrounded by an extensive area of $223 \mathrm{~km}^{2}$ used for rice cultivation, which was formerly part of the lake. Numerous irrigation ditches run through the area and end up in the lagoon, which is separated from the sea by a sand bar 500 to $1000 \mathrm{~m}$ wide. Three outlet channels with sluices connect the lake with the sea and allow the regulation of the water level according to the requirements for rice culturing. This determines the hydrological cycle of the lagoon, with a period of high water level during late autumn, when the paddies are flooded but contain no culture, a period of considerably high water flow during winter, driven by the draining of the flooded area, a period of low water renewal from May to September throughout the rice growing season, and a secondary period of moderately high water flow after harvest (end of September to October).

The study consisted of 2 sets of in situ experiments. The first set comprised 4 experiments that aimed to compare BP in winter versus summer conditions. Experiments were carried out on 23 to 25 February 2011, 24 and 25 January 2012, 22 February 2012, and 2 and 3 August 2011 at 2 different times, namely around noon and in the afternoon. BP was estimated at 3 depths: $0.2,0.8$, and $1.1 \mathrm{~m}$, applying both light and dark incubations. The experiments took place at a central location of the lagoon. The second set of experiments aimed to study diel variations in BP and comprised 2 diel cycles. BP was measured on the east shore of the lagoon on 24 and 25 April and 7 and 8 May 2012 approximately every $4 \mathrm{~h}$ at a depth of $0.6 \mathrm{~m}$. Water samples for all measured variables and BP experiments were collected with a Ruttner hydrographic bottle, except for those at $0.2 \mathrm{~m}$, which were collected with a jar, and kept in the dark and cold until they were processed.

\section{Limnological variables and bacterial enumeration}

Water conductivity, $\mathrm{pH}$, salinity, oxygen saturation $\left(\mathrm{O}_{2} \%\right)$, and temperature were measured in situ with a 
WTW Multi 350i set. Secchi disk depth was also recorded. Vertical profiles of photosynthetic active

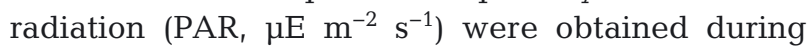
the experiments with a flat-faced quantum sensor (LiCor Li-1000). For the determination of dissolved inorganic nutrients and DOC, water subsamples were filtered on glass-fiber filters (GF/F, Whatman) upon arrival in the lab. Following the methodology described in APHA (1992), soluble reactive phosphorus (SRP-P) was determined by the Murphy and Riley method. Ammonia $\left(\mathrm{NH}_{4}-\mathrm{N}\right)$ was analyzed by the indophenol blue method, and the cadmium reduction method was used for the determination of both nitrate and nitrite $\left(\mathrm{NO}_{3}-\mathrm{N}, \mathrm{NO}_{2}-\mathrm{N}\right)$. Total nitrogen and total phosphorus were measured using the aforementioned methods for the respective dissolved fractions (SRP-P and $\mathrm{NO}_{2}-\mathrm{N} / \mathrm{NO}_{3}-\mathrm{N}$ ), after unfiltered samples underwent an acidic or alkaline digestion, respectively. Alkalinity (Alk) was determined by the Wattenber method. Total suspended solids (TSS) and loss on ignition (LOI) were also determined as specified in APHA (1992). The inorganic fraction of suspended solids was calculated by subtracting LOI from TSS. Soluble DOC and total organic carbon (TOC) were measured by high temperature combustion with a Total Organic Carbon Analyzer (Shimadzu TOC-VCSH) as described in ISO (1997). A standard solution of potassium hydrogen phthalate diluted in Milli-Q water was used for calibration. Chlorophyll a (chl a) concentrations were determined from samples collected onto glass-fiber filters $(\mathrm{GF} / \mathrm{F}$, Whatman). Filters were immediately placed inside a glass vessel and stored at $-80^{\circ} \mathrm{C}$ in the dark until they were processed. Chl a was extracted in a 1:1 (v/v) mixture of dimethyl sulfoxide (DMSO) and 90\% acetone as described by Shoaf \& Lium (1976) and analyzed spectrophotometrically.

Samples for enumeration of bacteria were preserved in a mixture of paraformaldehyde and glutaraldehyde $\left(100 \mathrm{~g} \mathrm{l}^{-1} \mathrm{wV}\right.$ and $0.5 \%$ final concentration, respectively) and stored at $4^{\circ} \mathrm{C}$ until they were processed. Subsamples were filtered on black polycarbonate filters $(0.2 \mu \mathrm{m}$, Millipore) and stained with DAPI (final concentration $20 \mu \mathrm{g} \mathrm{ml}^{-1}$ ) following a modification of the protocol described by Porter \& Feig (1980). Micrographs were taken on an epifluorescence microscope (Zeiss III RS), and then bacterial morphotypes were separately counted on them. Cell volume was estimated based on measurements of dimensions in these micrographs using the general formula as in Sommaruga (1995). Cell carbon content was then derived by applying a conversion factor of 0.2 pg $C \mu^{-3}$ (Simon \& Azam 1989).

\section{Bacterial ${ }^{3} \mathrm{H}$-leucine and ${ }^{3} \mathrm{H}$-thymidine incorporation experiments}

Leucine and thymidine incorporation rates (LIR and TIR) were measured by the ${ }^{3} \mathrm{H}$-leucine (Kirchman et al. 1985) and the ${ }^{3} \mathrm{H}$-thymidine (Fuhrman \& Azam 1982) methods, respectively, following the modification of the protocol described by Smith \& Azam (1992). Prior to water collection, L-[3, 4, 5- ${ }^{3} \mathrm{H}$ (N)]-Leucine (Perkin Elmer; specific activity 3.7 to $5.56 \mathrm{TBq} \mathrm{mmol}^{-1}$ ) was added to Eppendorf vials to obtain a final concentration of $10 \mathrm{nM}$. Thymidine, [Methyl- ${ }^{3} \mathrm{H}$ ] (Perkin Elmer; specific activity 2.59 to $3.33 \mathrm{TBq} \mathrm{mmol}^{-1}$ ) at a final sample concentration of $5 \mathrm{nM}$ was added to another set of vials. The vials were kept in the cold and dark until the beginning of the incubations. All experiments started immediately after water collection. For each depth and radiotracer, the collected water was distributed into 2 sets of 5 Eppendorf vials (sample volume $1.2 \mathrm{ml}$ ), each comprising 4 replicates plus a formalin-killed control. Each set of vials was then placed in a PAR-transparent or in an opaque Winkler bottle filled with water from the corresponding depth and hung from a buoy with a rope at the sampling depth. For the diel cycle experiments, only the PAR-transparent incubations were performed using 6 replicates plus 1 control. Incubations lasted $1 \mathrm{~h}$ in winter and spring or $45 \mathrm{~min}$ in summer and were stopped with $120 \mu$ of ice-cold $50 \%$ (5\% final concentration) trichloroacetic acid (TCA) and stored in ice until processed. In the lab, both samples and controls were centrifuged and aspirated, and the remaining pellets were rinsed with $1 \mathrm{ml}$ of $5 \%$ ice-cold TCA. The samples were centrifuged and aspirated again, and $1 \mathrm{ml}$ of scintillation cocktail (Sigma-Fluor (TM) High Performance LSC Cocktail, for aqueous samples, S4023) was added to the vials. Radioactivity of samples and radiolabeled solutions was measured with a PerkinElmer LSA Tri-Carb 2810TR liquid scintillation counter, and LIR and TIR were subsequently calculated. Incubation times were determined by time courses, which showed that LIR and TIR increases were linear for at least $1 \mathrm{~h} .{ }^{3} \mathrm{H}$-thymidine and ${ }^{3} \mathrm{H}$ leucine saturation courses were also performed. The obtained LIR and TIR were fitted to the hyperbolic function of Michaelis-Menten kinetics by iterative least-squares nonlinear regression analysis. Based on this regression, we verified that 5 and $10 \mathrm{nM}$ corresponded approximately to the half-saturation concentration for ${ }^{3} \mathrm{H}$-thymidine and ${ }^{3} \mathrm{H}$-leucine, respectively. The results therefore show that our experiments were performed at half-saturation con- 
centrations (i.e. data on LIR and TIR presented throughout the paper were obtained at half-saturation concentrations). For this reason and exclusively for the estimation of $\mathrm{BP}$, the obtained TIR values were multiplied by a factor of 2 to approximate them to those obtained at saturating levels. BP was calculated afterwards by applying a theoretical conversion factor of $2 \times 10^{18} \mathrm{cell} \mathrm{mol}^{-1}$ of incorporated ${ }^{3}$ H-thymidine (Ducklow \& Carlson 1992) and then multiplying by a mean cell carbon content value derived from the biovolume empirically obtained for each sample. Hourly areal bacterial production (HBP) was estimated by the trapezoidal method. Daily areal bacterial production (DBP) was calculated from the weighted average of HBP values at different day times.

\section{Statistical analyses}

Normality of data and homogeneity of variance were checked with Kolmogorov-Smirnov and Levene's tests, respectively, before data analysis. Oneway ANOVA, Kruskal-Wallis, or Mann-Whitney tests were used to analyze significant differences ( $\mathrm{p}<$ 0.05) in the measured variables with depth, light treatments, samplings times, or dates. Significant differences were further explored using post hoc analyses (Tukey $b$-test). Correlation between variables was estimated with Pearson's correlation coefficient (r). All statistical analyses were performed using SPSS Statistics 20.0 software.

\section{RESULTS}

\section{Environmental variables, bacterioplankton abundance, and biomass}

Water conductivity varied across experimental dates, being highest in February 2012. Water transparency was higher in winter and lower in spring as reflected by Secchi depth and chl a (Table 1). Chl a was in the range of hypertrophic lakes and displayed important seasonal variations, with spring values being up to 5 times higher than the minimum observed in February 2012. The water column was well mixed with $\mathrm{pH}$, temperature, and conductivity values that did not vary by more than $3 \%$ with depth. Inorganic nitrogen showed great seasonal variability, with high winter concentrations that decreased in spring and became distinctly lower in summer. TP-P and SRP-P concentrations also varied, showing higher values during spring and lower values in summer. DOC and TOC were higher in summer than on the other sampling dates (Table 1).

Bacterial abundance and biomass are shown in Table 1. Bacteria are grouped as (1) filamentous bacteria, with volumes up to $5.57 \mu^{3}$ and in some cases longer than $50 \mu \mathrm{m}$, (2) small cocci (cell diameter $<0.6 \mu \mathrm{m}$ and cell volume $<0.1 \mu^{3}$ ), and (3) 'other bacteria,' which included cocci (diameter 0.6$1.5 \mu \mathrm{m})$, bacilli (length 1-2.6 $\mu \mathrm{m}$ ), and curved bacteria (length $0.7-4 \mu \mathrm{m}$ ). Since bacterial aggregates only appeared sporadically (i.e. more than $99 \%$ of bacteria present were free-living organisms), particleattached bacteria were not taken into account. Hence, in this study, the term bacterial abundance refers to free-living bacterial abundance. Although filamentous bacteria represented only 3 to $13 \%$ of bacterial abundance, they amounted to as much as $78 \%$ of total bacterial biomass in both January and April 2012, averaging $60 \%$ in the other samplings. In contrast, small cocci were the most abundant group in all experiments, representing 44 to $64 \%$ of total abundance, but only a small portion of total biomass.

Bacterial abundance was fairly homogeneous across all experiments, ( $p>0.05$, ANOVA), whereas bacterial biomass displayed important variations. In both January and April 2012, bacterial biomass was significantly higher than in the other samplings $(\mathrm{p}<$ 0.05, ANOVA). On the other hand, bacterial biomass was significantly lower in May 2012 than on the other sampling dates ( $\mathrm{p}<0.05$, ANOVA). Further ANOVA comparisons performed for individual bacterial morphotypes showed that the biomass of filamentous bacteria was significantly higher both in January and April 2012 ( $p<0.05$, ANOVA) and significantly lower in May 2012 ( $p<0.05$, ANOVA). In contrast to bacterial biomass, bacterial abundance reached its minimum in January 2012.

During the diel cycle experiments, bacterial biomass was higher towards the end of the night. In May, variations were greater than in April (coefficients of variation of 21 and $11 \%$, respectively), with values after midnight twice as high as those observed in early morning. In May, bacterial abundance followed a diel pattern similar to that observed for incorporation rates, evidenced by its significant correlation with LIR ( $\mathrm{r}=0.98, \mathrm{p}<0.01, \mathrm{n}=6)$ or TIR $(\mathrm{r}=$ 0.88, $\mathrm{p}<0.05, \mathrm{n}=6$ ). During both cycles, bacterial biomass was positively correlated to $\mathrm{NO}_{3}-\mathrm{N}(\mathrm{r}=0.8$, $\mathrm{p}<0.01, \mathrm{n}=11), \mathrm{NO}_{2}-\mathrm{N}(\mathrm{r}=0.7, \mathrm{p}<0.05, \mathrm{n}=12)$ and negatively correlated to DOC $(\mathrm{r}=-0.82, \mathrm{p}<0.01$, $\mathrm{n}=12), \mathrm{NH}_{4}-\mathrm{N}(\mathrm{r}=-0.75, \mathrm{p}<0.01, \mathrm{n}=12)$, and SRP $(\mathrm{r}=-0.76, \mathrm{p}<0.01, \mathrm{n}=11)$. 
Table 1. Mean \pm SD of physicochemical and biological parameters during the experiments, showing significant differences $\left({ }^{*} \mathrm{p}<0.05,{ }^{* *} \mathrm{p}<0.01,{ }^{* * *} \mathrm{p}<0.001 ;\right.$ ANOVA/Kruskal-Wallis test) between experimental dates. Max: maximum value recorded during a sampling month.\%: percentage contribution of each morphotype to bacterial biomass. TN: total nitrogen; SRP: soluble reactive phosphorus; TP: total phosphorus; LOI: loss on ignition; TSS: total suspended solids; TSS - LOI: inorganic fraction of suspended solids

\begin{tabular}{|c|c|c|c|c|c|c|c|}
\hline & \multicolumn{2}{|c|}{$2011 \square$} & \multicolumn{4}{|c|}{2012} & \multirow{2}{*}{$\mathrm{p}$} \\
\hline & February & August & January & February & April & May & \\
\hline Temperature $\left({ }^{\circ} \mathrm{C}\right)$ & $14.7 \pm 0.22$ & $28.3 \pm 0.73$ & $11.5 \pm 0.44$ & $10.8 \pm 0.86$ & $19.26 \pm 0.97$ & $21.2 \pm 1$ & *** \\
\hline Secchi depth (m) & $0.50 \pm 0.02$ & $0.35 \pm 0.01$ & $0.45 \pm 0.04$ & $0.55 \pm 0.05$ & $0.23 \pm 0.03$ & 0.25 & - \\
\hline Conductivity $\left(\mu \mathrm{S} \mathrm{cm}^{-1}\right)$ & $1643 \pm 1.6$ & $1894 \pm 14.2$ & $1632 \pm 4.4$ & $2015 \pm 5.4$ & $1774+60$ & $1656 \pm 10$ & $* * *$ \\
\hline $\mathrm{O}_{2} \% \max$ & 145 & 141 & 152 & 137 & 197 & 181 & $*$ \\
\hline $\mathrm{pH}_{\max }$ & 8.65 & 8.98 & 8.8 & 8.78 & 9.48 & 10.05 & $* * *$ \\
\hline Alkalinity $\left(\mathrm{mg} \mathrm{l}^{-1}\right)$ & $36.7 \pm 3.1$ & $16.1 \pm 0.7$ & $34.7 \pm 0.6$ & $44.0 \pm 0.7$ & $14.8 \pm 1.4$ & $12.6 \pm 1.1$ & $* * *$ \\
\hline $\mathrm{NO}_{3}-\mathrm{N}\left(\mu \mathrm{gl}^{-1}\right)$ & $1957 \pm 81.8$ & $1.62^{\mathrm{a}}$ & $940 \pm 7.8$ & $3066^{\mathrm{a}}$ & $1029.6 \pm 195$ & $378.6 \pm 157$ & $* *$ \\
\hline $\mathrm{NO}_{2}-\mathrm{N}\left(\mu \mathrm{gl}^{-1}\right)$ & $114.3 \pm 2.3$ & $1.1^{\mathrm{a}}$ & $35.7 \pm 2.6$ & $125^{\mathrm{a}}$ & $56.6 \pm 4.1$ & $30.4 \pm 16$ & $* *$ \\
\hline $\mathrm{NH}_{4}-\mathrm{N}\left(\mu \mathrm{gl}^{-1}\right)$ & $41.1 \pm 15$ & $5.89^{a}$ & $40.3 \pm 5$ & $41.6^{\mathrm{a}}$ & $39.5 \pm 17$ & $140.8 \pm 53$ & $*$ \\
\hline TN-N $\left(\mu \mathrm{gl}^{-1}\right)$ & $4049 \pm 353$ & $3213^{\mathrm{a}}$ & $3364 \pm 2$ & $5476^{\mathrm{a}}$ & $5275 \pm 211$ & $4869 \pm 329$ & $* *$ \\
\hline $\operatorname{SRP}\left(\mu g \mathrm{l}^{-1}\right)$ & $0.83 \pm 0.8$ & $3.87^{\mathrm{a}}$ & $2.85 \pm 1.7$ & $2.16^{\mathrm{a}}$ & $3.7 \pm 1$ & $16.5 \pm 7.7$ & $*$ \\
\hline TP-P $\left(\mu g \mathrm{l}^{-1}\right)$ & $136 \pm 21$ & $106^{\mathrm{a}}$ & $122 \pm 4$ & $130^{\mathrm{a}}$ & $348 \pm 29$ & $272 \pm 15$ & $* *$ \\
\hline LOI $\left(\mathrm{mg} \mathrm{l}^{-1}\right)$ & $25.1 \pm 3$ & $55.9^{a}$ & $30 \pm 0.8$ & $20.7 \pm 0.8$ & $61 \pm 3$ & $62 \pm 3$ & $* * *$ \\
\hline $\mathrm{TSS}-\mathrm{LOI}\left(\mathrm{mg} \mathrm{l}^{-1}\right)$ & $16.3 \pm 5$ & $13.2^{\mathrm{a}}$ & $13.3 \pm 3$ & $5.6 \pm 2$ & $38 \pm 14$ & $38 \pm 5$ & $* * *$ \\
\hline $\begin{array}{l}\text { Dissolved organic } \\
\text { carbon }\left(\mathrm{mg} \mathrm{l}^{-1}\right)\end{array}$ & $7.7 \pm 0.2$ & $12.1 \pm 0.6$ & $7.7 \pm 0.1$ & $7.8 \pm 0.1$ & $7 \pm 0.1$ & $8 \pm 0.3$ & $* * *$ \\
\hline $\begin{array}{l}\text { Total organic carbon } \\
\left(\mathrm{mg} \mathrm{l}^{-1}\right)\end{array}$ & $13.5 \pm 1.2$ & $17.9 \pm 1.3$ & $12.8 \pm 0.7$ & $13.0 \pm 0.8$ & $14.4 \pm 0.9$ & $14.7 \pm 0.7$ & $* * *$ \\
\hline Chlorophyll a ( $\left.\mu g \mathrm{l}^{-1}\right)$ & $102 \pm 9$ & $113 \pm 10$ & $121 \pm 4$ & $64 \pm 1$ & $315 \pm 17$ & $301 \pm 5$ & $* * *$ \\
\hline $\begin{array}{l}\text { Unicellular bacterial abun- } \\
\text { dance }\left(10^{6} \text { cells } \mathrm{ml}^{-1}\right)\end{array}$ & $30.1 \pm 5.3$ & $24.5 \pm 2.1$ & $20.9 \pm 7.9$ & $22.4 \pm 2.4$ & $26.5 \pm 1$ & $25.4 \pm 2.7$ & NS \\
\hline $\begin{array}{l}\text { Filament abundance } \\
\left(10^{6} \text { filaments } \mathrm{ml}^{-1}\right)\end{array}$ & $1.8 \pm 0.3$ & $2.9 \pm 0.5$ & $2.5 \pm 0.4$ & $1.6 \pm 0.3$ & $3.1 \pm 0.4$ & $1890 \pm 606$ & ${ }^{* * *}$ \\
\hline Bacterial biomass $\left(\mathrm{mg} \mathrm{C}^{-1}\right.$ ) & $2.30 \pm 0.25$ & $2.46 \pm 0.37$ & $3.04 \pm 0.36$ & $2.31 \pm 0.24$ & $3.03 \pm 0.32$ & $1.63 \pm 0.3$ & * \\
\hline$\%$ Small cocci $(\varnothing<0.6 \mu \mathrm{m})$ & $16 \pm 4$ & $10 \pm 1$ & $7 \pm 2$ & $11 \pm 2$ & $11 \pm 1$ & $22 \pm 11$ & $* * *$ \\
\hline$\%$ Cocci & $7 \pm 2$ & $6 \pm 1$ & $7 \pm 2$ & $7 \pm 2$ & $5 \pm 1$ & $7 \pm 1$ & ${ }^{*}$ \\
\hline$\%$ Bacilli & $9 \pm 1$ & $21 \pm 1$ & $8 \pm 1$ & $16 \pm 3$ & $8 \pm 1$ & $18 \pm 1$ & * \\
\hline$\%$ Curved bacteria & $5 \pm 1$ & $3 \pm 1$ & $3 \pm 0.7$ & $4 \pm 0.7$ & $2 \pm 0.4$ & $4 \pm 1$ & * \\
\hline$\%$ Filamentous bacteria & $63 \pm 6$ & $60 \pm 2$ & $76 \pm 2$ & $62 \pm 11$ & $74 \pm 3$ & $50 \pm 10$ & * \\
\hline
\end{tabular}

\section{Incorporation rates}

LIR and TIR showed only moderate changes across experimental dates. Variations did not reflect a seasonal pattern, although in February 2012, a decrease was observed during a period of high water discharge through the lagoon and minimum chl a concentrations. LIR ranged from 49 to $391 \mathrm{pmol} \mathrm{l}^{-1} \mathrm{~h}^{-1}$ (mean $\pm \mathrm{SE}=201 \pm 4.4, \mathrm{n}=208)$, whereas TIR ranged from 13 to $62 \mathrm{pmol} \mathrm{l}^{-1} \mathrm{~h}^{-1},(31 \pm 0.6, \mathrm{n}=217)$. The overall correlation between LIR and TIR when considering all experiments was significant $(\mathrm{r}=0.62, \mathrm{p}<$ 0.001, $\mathrm{n}=60$ ).

No clear pattern of LIR or TIR arose with depth. Nevertheless, LIR and TIR at $0.2 \mathrm{~m}$ were repeatedly higher than at 0.8 and/or $1.1 \mathrm{~m}$ ( $\mathrm{p}<0.05$, KruskalWallis test) (Fig. 1). Only differences between light and dark incubations at $0.2 \mathrm{~m}$ are shown in Fig. 2, given the low light intensity recorded at the other depths. Although both LIR and TIR were generally higher in the light than in the dark, significant differences were only obtained in some light to dark comparisons, and these differences were small. Characteristically, no significant differences were found in summer.

The average light to dark ratio at $0.2 \mathrm{~m}$ for LIR was $1.09 \pm 0.08$ and showed no correlation with any of the measured parameters. Interestingly, when considering data from all depths, the overall light to dark ratio for LIR (average $=1.09 \pm 0.2$ ) was positively correlated to $\mathrm{NH}_{4}-\mathrm{N}(\mathrm{r}=0.54, \mathrm{p}<0.05, \mathrm{n}=14)$. At $0.2 \mathrm{~m}$, the average light to dark ratio for TIR was $1.07 \pm 0.08$. This ratio was negatively correlated with PAR ( $\mathrm{r}=$ $-0.75, \mathrm{p}<0.05, \mathrm{n}=8)$ and with $\mathrm{T}(\mathrm{r}=-0.74, \mathrm{p}<0.05$, 


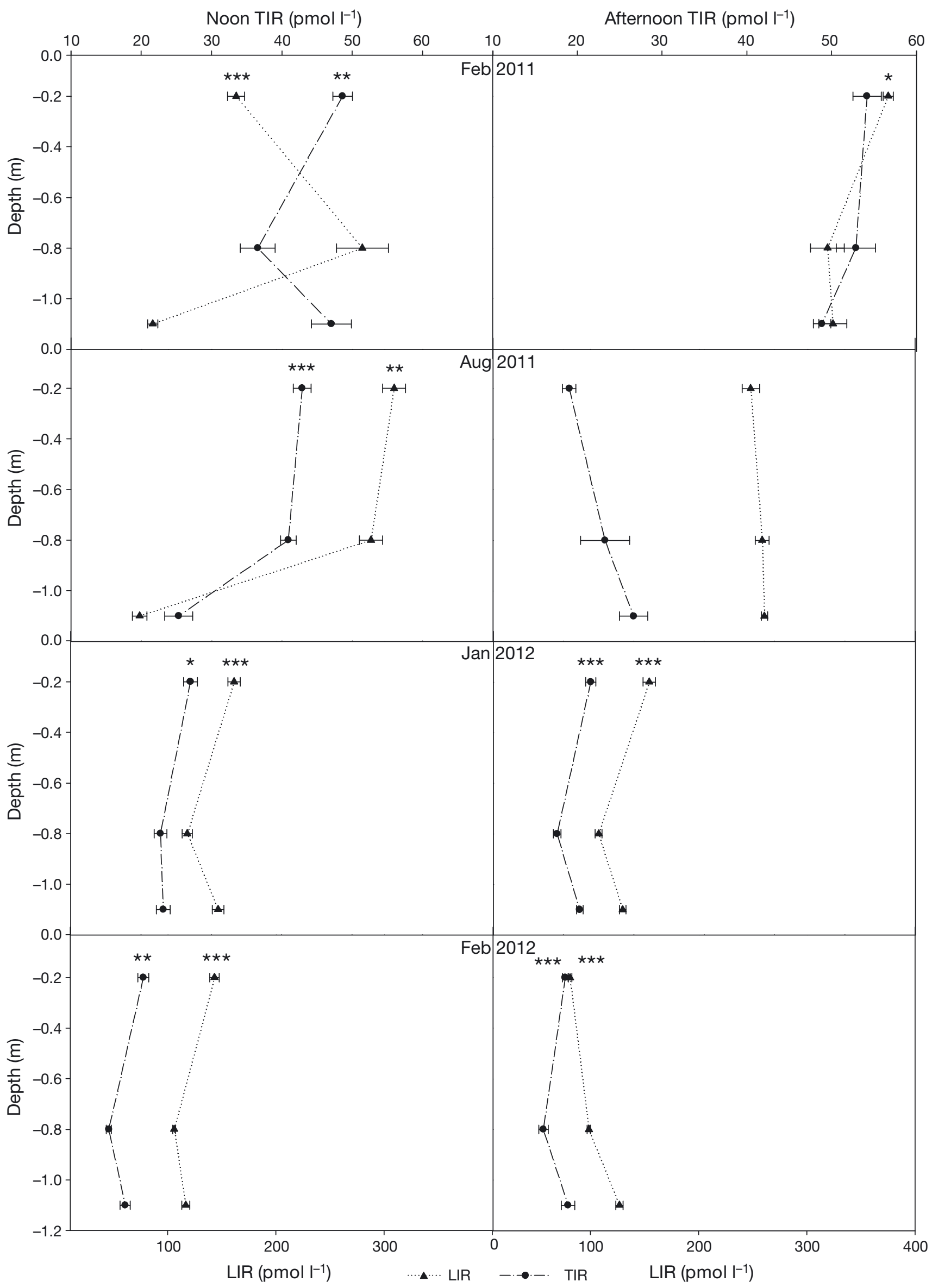


Fig. 1. Incorporation rates of ${ }^{3} \mathrm{H}$-leucine (LIR) and ${ }^{3} \mathrm{H}$-thymidine (TIR) at 3 depths. Plotted data are mean values from all incubations (light and dark) at each depth. Error bars represent standard error. Significant differences between depths ( $p<0.05$, Kruskal-Wallis test) are indicated by asterisks: ${ }^{*} \mathrm{p}<0.05,{ }^{* *} \mathrm{p}<0.01,{ }^{* * *} \mathrm{p}<0.001$

$\mathrm{n}=8$ ). When considering data from all depths, the overall light to dark ratio for TIR was negatively correlated to DOC $(\mathrm{r}=-0.45, \mathrm{p}<0.05, \mathrm{n}=24)$.

\section{Diel cycle experiments}

Bacterial incorporation rates showed a diel pattern during both cycles characterized by an increase throughout the night followed by a marked decrease at sunrise (Fig. 3). This pattern was far more apparent in April, as reflected by the higher LIR and TIR coefficients of variation (Fig. 3). It is noteworthy that DOC displayed an obvious diel pattern during both cycles that opposes those found for LIR and TIR (Fig. 3). Significant differences between sampling times were found for both LIR and TIR and in both cycles (KruskalWallis, $\mathrm{p}<0.001)$. In April, further post hoc analyses showed that LIR and TIR during night experiments were significantly higher than at 18:00 and 08:30 h. Moreover, they were higher at 14:00 h than at the other times. In May, additional post hoc analyses showed that both LIR and TIR were higher at 05:00 $\mathrm{h}$ than at the other times, and LIR was significantly higher during hours of darkness than during daylight. Diel
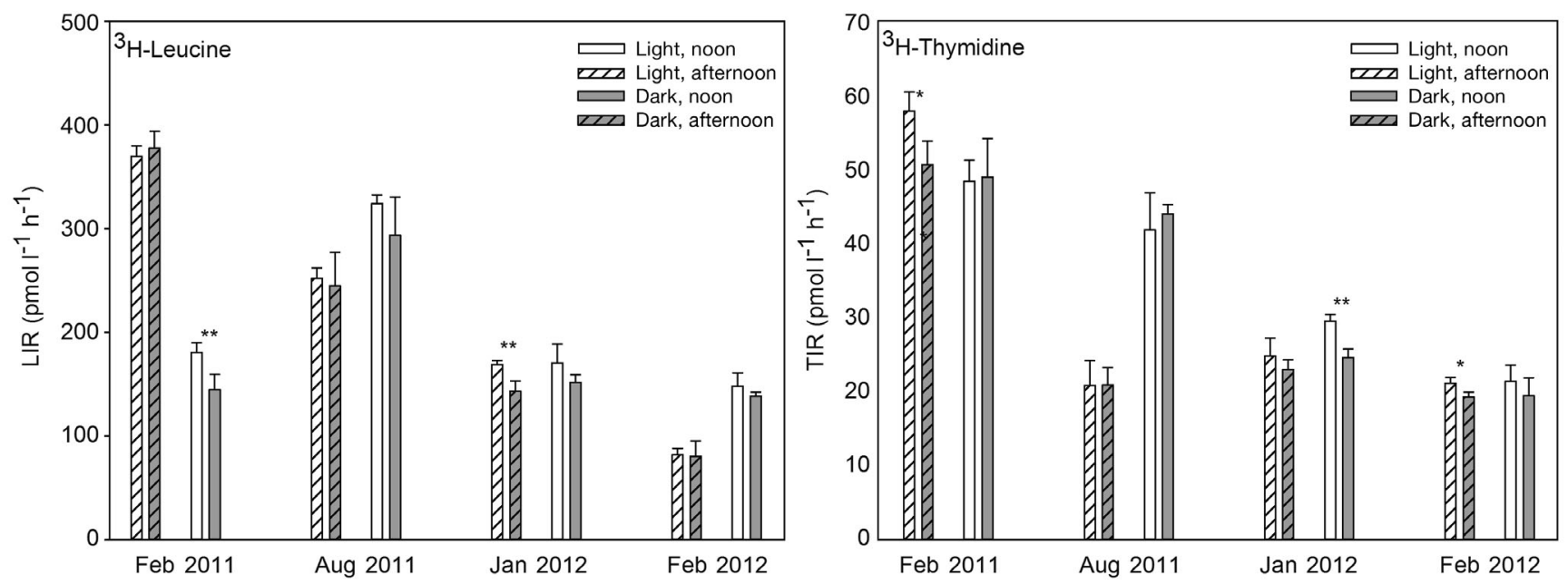

Fig. 2. Incorporation rates of ${ }^{3} \mathrm{H}$-leucine (LIR) and ${ }^{3} \mathrm{H}$-thymidine (TIR) at $0.2 \mathrm{~m}$. Error bars represent standard deviations. Significant differences between light and dark incubations ( $p<0.05$, ANOVA test) are indicated by asterisks: ${ }^{*} p<0.05,{ }^{* *} p<0.01$
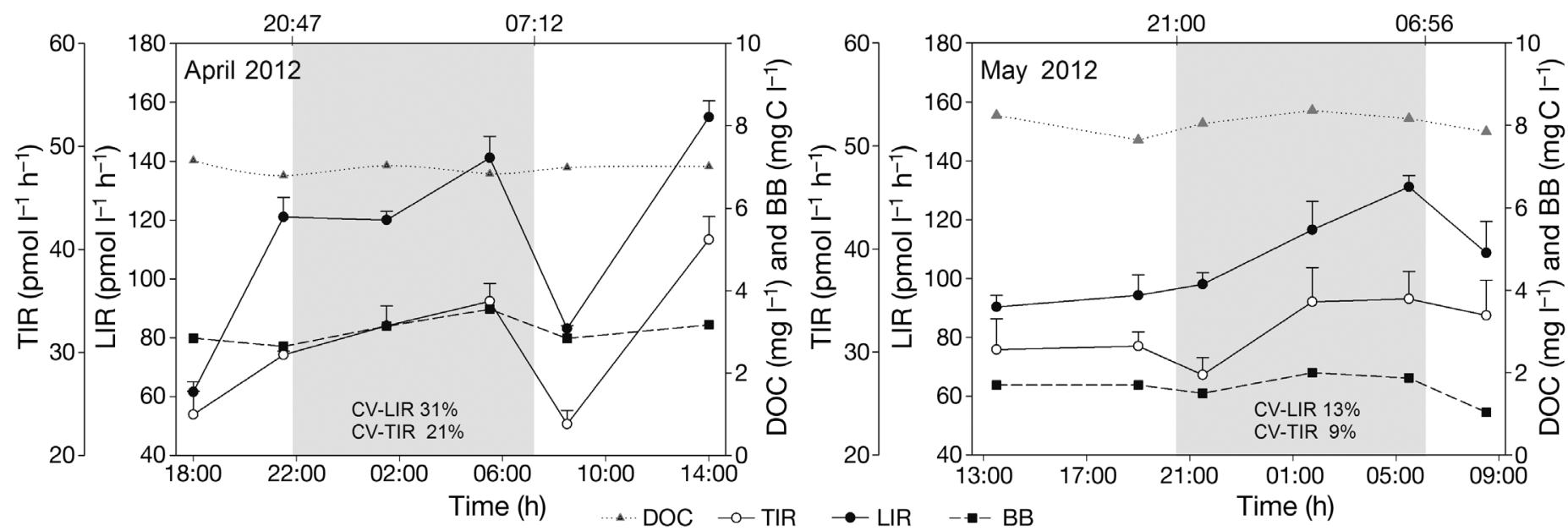

Fig. 3. Diel changes in dissolved organic carbon (DOC), bacterial biomass (BB), and incorporation rates of ${ }^{3} \mathrm{H}-\mathrm{leucine}(\mathrm{LIR})$ and ${ }^{3} \mathrm{H}-$ thymidine (TIR) during 2 diel cycles. Coefficients of variation for LIR (CV-LIR) and TIR (CV-TIR) are also given. Error bars represent standard deviations. Local times for sunrise and sunset are also indicated on the top axis 
variations in LIR and TIR practically paralleled each other in both cycles (Fig. 3), as shown by the strong correlation between LIR and TIR $(r=0.89, p<0.001$, $\mathrm{n}=12$ ), although changes in TIR were appreciably less distinct than in LIR, which varied over a wider range.

\section{Relationship between LIR and TIR}

During the winter and summer experiments, the average LIR:TIR ratio was 6.39, and most values were close to this number, although in the experiments performed in summer and in the morning in February 2011, the ratio displayed wider variability (Fig. 4a). No significant differences in the LIR:TIR ratio were found between depths or light treatments ( $p>0.05$, ANOVA), but when the experimental dates were compared, the ratio in the summer afternoon experiment was significantly higher $(\mathrm{p}>0.001$, ANOVA). The LIR:TIR ratio in light-incubated samples was positively correlated with $\mathrm{T}(\mathrm{r}=0.56, \mathrm{p}<$ $0.01, \mathrm{n}=24), \mathrm{pH}(\mathrm{r}=0.68, \mathrm{p}<0.001, \mathrm{n}=24)$, and DOC $(\mathrm{r}=0.61, \mathrm{p}<0.01, \mathrm{n}=24)$.

During the spring experiments, the LIR:TIR ratio averaged 3.6 (SD 0.55) and 3.2 (SD 0.28) in April and in the May cycles, respectively, and did not differ significantly between both months. The LIR:TIR ratio showed only small variations throughout the diel cycle, with coefficients of variation of 15 and $8 \%$ in April and in May, respectively. Interestingly, the LIR:TIR ratio showed the same diel pattern in both cycles (Fig. 4b), with an increase after sunset and

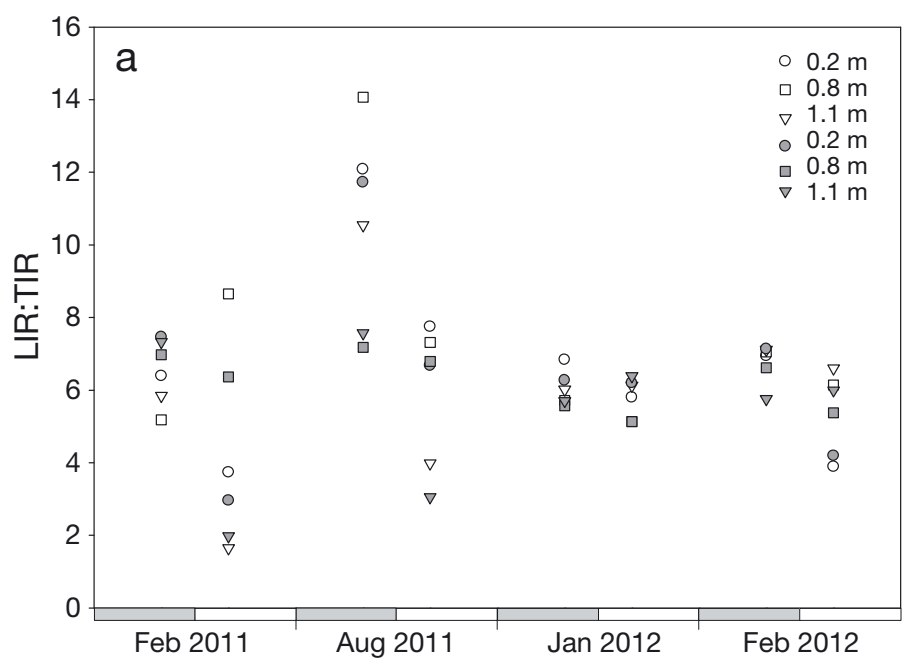

higher values during the night hours. When winter, spring, and summer data were pooled, a positive correlation was found between the LIR:TIR ratio and DOC $(r=0.68, p<0.001, n=36)$.

\section{Bacterial production}

BP varied from 5 to $20.6 \mathrm{mg} \mathrm{C} \mathrm{m}{ }^{-3} \mathrm{~h}^{-1}$. Because mean depth at Albufera is approximately $1 \mathrm{~m}$, HBP was rather similar to BP. HBP did not display important seasonal variations (Fig. 5). Maximum values were observed in April 2012, whereas minimum

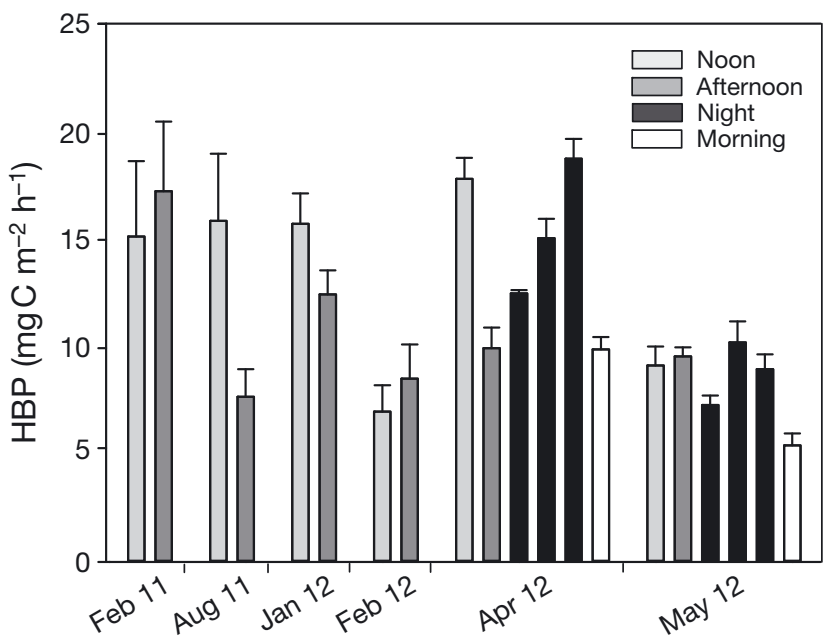

Fig. 5. Hourly areal bacterial production (HBP). The chronological order of April sampling times has been modified in order to obtain a comparable sequence between months

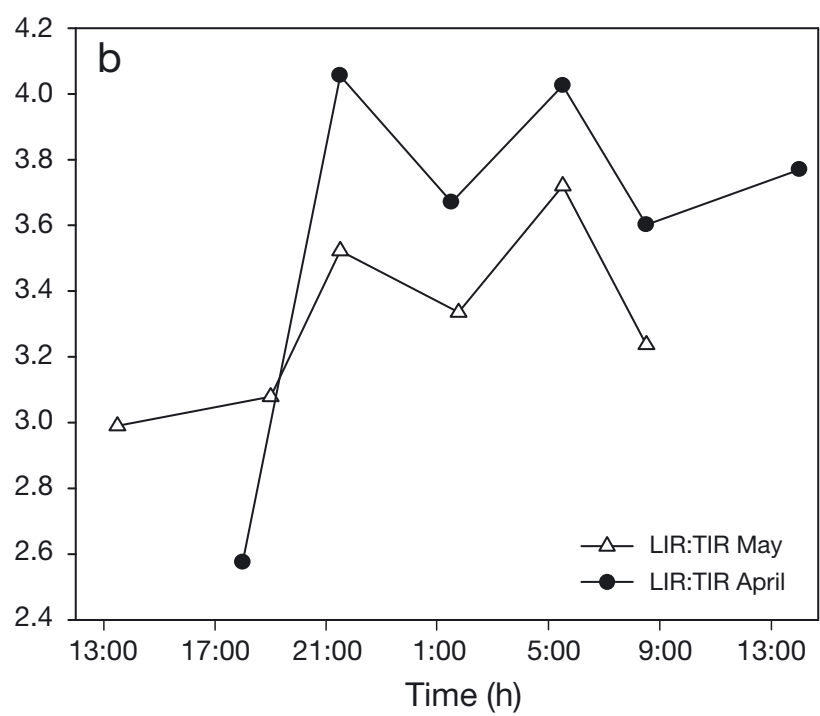

Fig. 4. (a) Ratio of ${ }^{3} \mathrm{H}$-leucine to ${ }^{3} \mathrm{H}$-thymidine incorporation rates (LIR:TIR) at 3 depths. White and dark symbols represent light and dark incubations, respectively. White and gray bars on the $x$-axis represent noon and afternoon, respectively. (b) LIR:TIR ratio during diel cycle experiments 
values concurred with the lowest values of chl $a$ and the highest water transparency in February 2012. During the winter-summer experiments, BP was positively correlated to chl a $(\mathrm{r}=0.47, \mathrm{p}<0.005, \mathrm{n}=24)$. During the diel cycle experiments, BP was negatively correlated to DOC ( $\mathrm{r}=-0.68, \mathrm{p}<0.05, \mathrm{n}=12)$ and $\mathrm{NH}_{4}-\mathrm{N}(\mathrm{r}=-0.61, \mathrm{p}<0.05, \mathrm{n}=12)$. BP was significantly higher in April than in May $(\mathrm{p}<0.01, \mathrm{n}=12$, Mann-Whitney).

\section{DISCUSSION}

\section{Bacterioplankton abundance and biomass}

Bacterial abundance was very high but within the range typically registered in the literature for hypertrophic lakes. In accordance with our results of approximately 22-32 $\left(\times 10^{6}\right)$ cells $\mathrm{ml}^{-1}$, values of $1-30$ $\left(\times 10^{6}\right)$ cells $\mathrm{ml}^{-1}$ were found in a study including 55 highly enriched lakes (Auer et al. 2004). Sommaruga (1995) reported values which were higher in summer (up to $20 \times 10^{6}$ cells $\mathrm{ml}^{-1}$ ), but in contrast to his findings, in our work bacterial abundance remained practically unchanged across seasons. We attribute the considerable bacterial abundance to the high turbulence characteristic of this large shallow lagoon, which favors sediment resuspension and thereby the return of nutrients to the water column, resulting in a high nutrient availability for bacteria. This is indicated by high LOI and TTS - LOI values, but also by the high nutrient concentrations and the low Secchi values observed (Table 1). Similar conclusions were suggested for the Neusiedlersee (Austria) by Dokulil (1984).

The attached:free-living bacteria ratio was low when compared to other hypertrophic lakes (PedrósAlió \& Brock 1982, Torréton et al. 1994). This might be explained by the fact that in Albufera, algae are the major contributors to seston (G. Onandia et al. unpubl. data) and, thus, the amount of particulate detritus to which bacteria can be attached is small. In this respect, Albufera contrasts with other productive systems, where particulate detritus in the form of dead organic matter has been found to surpass particulate organic matter present as living material (Wetzel et al. 1972).

Bacterial biomass(1-3.6 mg $\mathrm{C}^{-1}$ ) was greater than the values of 74 and $563 \mu \mathrm{g} \mathrm{C} 1^{-1}$ reported by Auer et al. (2004) and Chrost et al. (2000), respectively, and exceeded the range of 80-443 $\mu \mathrm{g} \mathrm{C}^{-1}$ described by Sommaruga (1995) because of large cell volumes. In our study, bacterial community mean cell volumes ranged from 0.18 to $0.76 \mu^{3}$ due to the permanent presence of filamentous bacteria. Seasonal variations in bacterial biomass were caused mainly by differences in the proportions of this group. The high bacterial cell volumes observed in winter agreed with findings from Lake Rodó in Uruguay (Sommaruga \& Psenner 1995), where cell volumes were inversely correlated to water temperature and there was a similar proportion of filamentous bacteria $(4.5-16 \%)$ to our study (3-13\%).

\section{Incorporation rates of radiotracers}

Variations in LIR were greater than those in TIR, in accordance with observations in meso-eutrophic Lake Constance (Germany) and in the north-western Mediterranean Sea (Simon 1994, Gasol et al. 1998). Because LIR and TIR were estimated at half-saturation concentrations, the given values roughly correspond to half of those to be attained at saturating levels. Jørgensen (1992) stressed that natural leucine concentrations may influence the measured incorporation rates in eutrophic lakes due to extracellular isotope dilution. Using saturation leucine concentrations of $100 \mathrm{nM}$, that author obtained incorporation rates of 200 to $1450 \mathrm{pmol} \mathrm{l}^{-1} \mathrm{~h}^{-1}$ in Lake Bagsvaerd and 70 to $225 \mathrm{pmol} \mathrm{l}^{-1} \mathrm{~h}^{-1}$ in Frederikborg Castle Lake, located in Denmark. Simultaneous measurements performed with $10 \mathrm{nM}$ leucine concentrations yielded LIR of 20 to $125 \mathrm{pmol} \mathrm{l}^{-1} \mathrm{~h}^{-1}$ in the latter lake. Our LIR values (49-391 $\mathrm{pmol} \mathrm{l}^{-1} \mathrm{~h}^{-1}$ ) were generally lower than reported values for highly enriched lakes such as the shallow eutrophic Lake Layrac in France, with 1203 pmol l $^{-1} \mathrm{~h}^{-1}$ ) Petit et al. 1999) or Lake Oglethorpe in the USA, with 600 to $6000 \mathrm{pmol} \mathrm{l}^{-1}$ $\mathrm{h}^{-1}$ (McDonough et al. 1986).

TIR (13-62 pmol $\mathrm{l}^{-1} \mathrm{~h}^{-1}$ ) agreed with values previously reported for eutrophic lakes such as Frederiksborg Castle and Bagsvaerd (Jørgensen 1992), where values were up to approximately $60 \mathrm{pmol} \mathrm{l}^{-1} \mathrm{~h}^{-1}$. Likewise, Petit et al. (1999) observed $25.6 \mathrm{pmol}^{-1} \mathrm{~h}^{-1}$ in Lake Laryac, and McDonough et al. (1986) found 1 to $40 \mathrm{pmol} \mathrm{l}^{-1} \mathrm{~h}^{-1}$ in Lake Oglethorpe. However, the thymidine concentrations used in our work were lower than those (10-20 nM) used in the aforementioned studies (with the exception of lake Laryac, $5 \mathrm{nM}$ ) and in other hypertrophic systems such as Lake Verevi in Estonia and Lake Szymon in Poland (Chrost et al. 2000, Tammert et al. 2005).

Contradictory results of both light stimulation and inhibition on the incorporation rates of radiotracers have been documented (Gasol et al. 2008, RuizGonzález et al. 2013), indicating a complex relation- 
ship between PAR and BP. Research of the effects of natural solar radiation in hypertrophic lakes is very limited, but numerous studies have been performed in the ocean and in less enriched freshwater systems. Studies performed in the southwest lagoon of New Caledonia showed that both PAR and PAR plus different fractions of ultraviolet radiation inhibited TIR (Conan et al. 2008, Rochelle-Newall et al. 2008). Lindell et al. (1996) described inhibition or no effect of sunlight on LIR in 5 oligotrophic lakes in southern Sweden, and inhibitory effects of full solar radiation on LIR and TIR were described in a mesotrophic estuary in Florida (Aas et al. 1996), which in part might have been due to ultraviolet radiation. However, higher TIR under light than under dark conditions were observed in a hypertrophic lake (Sommaruga \& Robarts 1997). Similarly, enhanced LIR and TIR under artificial light were found in littoral sea waters (RuizGonzález et al. 2012). In the present study, in which only PAR was taken into account, both LIR and TIR in the light were generally slightly higher than in the dark, in accordance with the findings of Sommaruga \& Robarts (1997) and Ruiz-González et al. (2012). Nonetheless, our results indicate a possible interaction between light and other parameters. Nutrient availability has been highlighted by previous studies in the ocean (Morán et al. 2001) and seems to play an important role in amino acid uptake in Albufera de Valencia given the positive correlation found between the light:dark ratio of LIR and $\mathrm{NH}_{4}-\mathrm{N}$. Moreover, a negative correlation was found between the TIR light:dark ratio and variables with higher values in summer such as DOC. No significant differences between light treatments were found for any of the radiotracers in summer, whereas some significant differences were observed during winter experiments. The results suggest that light influence on incorporation rates is not detected when DOC concentrations are very high but it may interfere when DOC is lower. A possible underlying mechanism cited in a recent review (Ruiz-González et al. 2013) is the indirect enhancement of bacterial activity in light-incubated over dark-incubated samples through higher phytoplankton extracellular organic release availability.

\section{Diel cycle experiments}

Our results indicate that in Albufera de Valencia, diel changes in BP are related to the availability of DOC. As BP increases, DOC is depleted from the water column, yielding a negative correlation between these variables. If we consider that given the extremely high primary production in the lagoon in spring (G. Onandia et al. unpubl. data), autochthonous DOC very likely overshadowed the contribution of allocthonous DOC to the DOC total pool; this relationship suggests that BP is dependent upon the extracellular organic release from phytoplankton. Significant correlations between BP and $\mathrm{NH}_{4}-\mathrm{N}$, $\mathrm{NO}_{3}-\mathrm{N}$, or SRP-P were also observed, but it is difficult to exclusively attribute this relationship to bacterial activity, given the tight interplay between these nutrients and other biological food web components such as primary producers and zooplankton.

Diel cycles in BP have been observed in other eutrophic lakes. Diurnal variations were reported for the hypertrophic Lake Verevi, with highest values in the afternoon (Tammert et al. 2005), although no night measurements were performed in this study. In agreement with our results, higher BP towards and during the night has been found in several eutrophic shallow lakes (e.g. Bagsvaerd, Võrtsjärv, and Bietri, Jørgensen 1992, Torréton et al. 1994, Kisand et al. 1998) and in the deep meso-eutrophic Lake Constance during the spring bloom (Simon 1994). In the latter study, a peak in leucine-estimated BP at noon was observed in accordance with our observations during the April diel cycle. However, the same author found inconsistent diel cycles of bacterial activity after the decline of the spring diatom bloom, coinciding with previous observations in eutrophic waters (Riemann \& Søndergaard 1984).

\section{Relationship between LIR and TIR}

BP has been extensively measured with ${ }^{3} \mathrm{H}$-thymidine and to a lesser degree with ${ }^{3} \mathrm{H}$-leucine, whose incorporation reflect DNA and protein synthesis, respectively. The combined use of both radiotracers constitutes an assessment tool for the reliability of BP estimates, providing independent BP values (Kirchman et al. 1985, Chin-Leo \& Kirchman 1990, FrancoVidal \& Moran 2011). Therefore, the significant correlation found between LIR and TIR verifies the reliability of the measurements performed in this work. The incorporation ratio of LIR to TIR reflects the growth state of the bacterial community (ChinLeo \& Kirchman 1988, Hoppe et al. 2006). In balanced growth conditions, the LIR:TIR ratio is expected to be constant (Gasol et al. 1998). The correlation found between LIR and TIR, and the relative constancy of the LIR:TIR ratio within seasons, suggests that synthesis of DNA and proteins were coupled. Nonetheless, the wider variability observed during 
some samplings possibly indicates changes in bacterial growth state. We found a positive correlation of the LIR:TIR ratio with temperature, which has been found to modulate this quotient in different aquatic systems, although not always in the same way. Whereas an inverse relation was described during a seasonal study in mesotrophic Lake Paralepoup in France (Petit et al. 1999) and during temperature manipulation experiments (Shiah \& Ducklow 1997), a positive relation was found in the ocean (Longnecker et al. 2006) and in a range of marine and freshwater systems (Tibbles 1996).

The high correlation found between LIR and TIR along diel cycles indicates balanced growth of the bacterial community during spring. Changes in the LIR: TIR ratio were small, meaning that at the short time scale at which experiments were done, no shift in bacterial growth rate took place. However, though small, the similar diel pattern changes in the LIR:TIR ratio observed along both diel cycles suggest that during sunset, protein synthesis is slightly favored over DNA synthesis. Few studies involving the simultaneous use of both radiotracers during diel cycles are available in freshwater ecosystems, but it is noteworthy that a similar increase in the LIR:TIR ratio towards the evening was found in Lake Bagsvaerd (Jørgensen 1992) and in Laguna Madre, a hypersaline, shallow coastal lagoon located in Texas (Chin-Leo \& Benner 1991).

Seasonal variations in the LIR:TIR ratio seemed to be related to DOC availability, with higher concentrations of DOC favoring protein synthesis. These results contrast with the hypothesis that bacteria tend to allocate more resources into biomass accumulation under adverse environmental conditions (Petit et al. 1999). Even though our LIR:TIR ratio values (1.7-14) should be interpreted as an approximation, given that LIR and TIR were measured below saturating concentrations, they are close to the average found when considering a large range of aquatic systems: 7.0-9.5 (Servais 1992) and to the value of 9.1 reported for a eutrophic Danish lake (Riemann \& Bell 1990).

\section{Bacterial carbon production}

BP values plotted in Fig. 5 should be considered as rough estimates due to the uncertainties in the conversion of our TIR data into BP (i.e. we did not work at thymidine saturating concentrations, and a theoretical conversion factor was applied for the estimation of produced cells from TIR). The conversion factor of $2 \times 10^{18}$ cells mol$^{-1}$ of incorporated ${ }^{3} \mathrm{H}$-thymidine (Ducklow \& Carlson 1992) used in the present study has been widely used in the literature and more specifically in other hypertrophic lakes, such as Lake Verevi (Tammert et al. 2005). This conversion factor is close to the range of 1.9 to $2.2 \mathrm{cells} \mathrm{mol}^{-1}$ obtained for a Swedish eutrophic lake (Bell et al. 1983), the average value of $2.15 \times 10^{18} \mathrm{cells} \mathrm{mol}^{-1}$ observed for freshwater bacteria (Smits \& Riemann 1988), and the value of $2.2 \times 10^{18}$ cells mol $^{-1}$ obtained in the eutrophic Little Crooked Lake in Indiana (Lovell \& Konopka 1985). However, it should be noted that empirically derived conversion factors have been seen to vary temporarily and in relation to environmental aspects, such as nutrient concentrations, highlighting the importance of specific experimental determinations (Calvo-Díaz \& Morán 2009). Therefore, future studies involving the estimation of empirical conversion factors are needed in order to more accurately quantify bacterial carbon production in this particular ecosystem. Nonetheless, since cell carbon content was based on bacterial biovolume calculated from microscopic observations for each experimental date, bacterial shape and biovolume were specifically addressed in our BP calculations. In spite of the mentioned uncertainties, the obtained HBP values (5.4-18.8 $\mathrm{mg} \mathrm{C} \mathrm{m}^{-2} \mathrm{~h}^{-1}$ ) were close to the range of 0.62 to $11 \mathrm{mg} \mathrm{C} \mathrm{m}^{2} \mathrm{~h}^{-1}$ reported by Kisand et al. (1998) and to the values found by Petrucio \& Barbosa (2004) in shallow Lake Carioca in Brazil $(5.7 \mathrm{mg}$ $\mathrm{C} \mathrm{m}^{-2} \mathrm{~h}^{-1}$ ). DBP (186-390 $\mathrm{mg} \mathrm{C} \mathrm{m}^{-2} \mathrm{~d}^{-1}$ ) was also comparable to the values of 19.8 to $422 \mathrm{mg} \mathrm{C} \mathrm{m}^{-2} \mathrm{~d}^{-1}$ and $354 \mathrm{mg} \mathrm{C} \mathrm{m}^{-2} \mathrm{~d}^{-1}$ observed in the hypertrophic Lakes Humboldt (in Canada) and Verevi, respectively (Robarts et al. 1994, Tammert et al. 2005). Similarly, daily volumetric BP $\left(154-706 \mathrm{mg} \mathrm{C} \mathrm{m}^{-3} \mathrm{~d}^{-1}\right)$ was close to the range of 217 to $796 \mathrm{mg} \mathrm{C} \mathrm{m}^{-3} \mathrm{~d}^{-1}$ reported for Lake Szymon (Chrost et al. 2000) and similarly agreed with estimations in Lake Rodó (72-1071 mg C m ${ }^{-3} \mathrm{~d}^{-1}$, Sommaruga 1995).

In conclusion, no major seasonal variations in BP were observed, in contrast with the important changes typically experienced by the phytoplankton community along the annual succession. However, a distinct PB decrease was observed as flushing clarified the water in late winter (indicated by a chl a minimum in February 2012), which was followed by a marked rise in spring, when chlorophyll peaked. We found an evident BP diel pattern in hypertrophic conditions, and this pattern was coupled to variations in DOC, suggesting a possible dependence of bacterioplankton on primary production. In view of the values reported in the literature, we can conclude that BP was high, although it did not surpass previous measurements in hypertrophic systems. 
Acknowledgements. This research was supported by the Spanish Ministry of Economy and Competitiveness through the project CGL2009-12229. We thank the rangers of the Oficina Técnica Devesa-Albufera and X. Soria for their assistance in the field in 2011 and 2012, respectively. We likewise thank J. M. Soria and O. Kramer for their help in the laboratory. We are also grateful to J. M. Gasol for his methodological advice and to C. Rochera, A. Camacho and 3 anonymous reviewers for their valuable comments.

\section{LITERATURE CITED}

Aas P, Lyons MM, Pledger R, Mitchell DL, Jeffrey WH (1996) Inhibition of bacterial activities by solar radiation in nearshore waters and the Gulf of Mexico. Aquat Microb Ecol 11:229-238

APHA (American Public Health Association) (1992) Standard methods for the examination of water and wastewater. American Public Health Association, Washington, DC

Auer B, Elzer U, Arndt H (2004) Comparison of pelagic food webs in lakes along a trophic gradient and with seasonal aspects: influence of resource and predation. J Plankton Res 26:697-709

> Azam F, Fenchel T, Field JG, Gray JS, Meyer-Reil LA, Thingstad F (1983) The ecological role of water-column microbes in the sea. Mar Ecol Prog Ser 10:257-263

Baines SB, Pace ML (1991) The production of dissolved organic matter by phytoplankton and its importance to bacteria: patterns across marine and freshwater systems. Limnol Oceanogr 36:1078-1090

> Bell RT, Ahlgren GM, Ahlgren I (1983) Estimating bacterioplankton production by measuring $\left[{ }^{3} \mathrm{H}\right]$ thymidine incorporation in a eutrophic Swedish lake. Appl Environ Microbiol 45:1709-1721

Calvo-Díaz A, Morán XAG (2009) Empirical leucine-to-carbon conversion factors for estimating heterotrophic bacterial production: seasonality and predictability in a temperate coastal ecosystem. Appl Environ Microbiol 75: 3216-3221

Chin-Leo G, Benner R (1991) Dynamics of bacterioplankton abundance and production in seagrass communities of a hypersaline lagoon. Mar Ecol Prog Ser 73:219-230

Chin-Leo G, Kirchman DL (1988) Estimating bacterial production in marine waters from the simultaneous incorporation of thymidine and leucine. Appl Environ Microbiol 54:1934-1939

Chin-Leo G, Kirchman DL (1990) Unbalanced growth in natural assemblages of marine bacterioplankton. Mar Ecol Prog Ser 63:1-8

Chrost R, Koton M, Siuda W (2000) Bacterial secondary production and bacterial biomass in four Mazurian lakes of differing trophic status. Pol J Environ Stud 9: 255-266

$>$ Cole JJ, Findlay S, Pace ML (1988) Bacterial production in fresh and saltwater ecosystems: a cross-system overview. Mar Ecol Prog Ser 43:1-10

- Conan P, Joux F, Torretón JP, Pujo-Pay M, Douki T, Rochelle-Newall E, Mari X (2008) Effect of solar ultraviolet radiation on bacterio- and phytoplankton activity in a large coral reef lagoon (southwest New Caledonia). Aquat Microb Ecol 52:83-98

> Dokulil M (1984) Assessment of components controlling phytoplankton photosynthesis and bacterioplankton pro- duction in a shallow, alkaline, turbid lake (Neusiedlersee, Austria). Int Rev Gesamten Hydrobiol 69:679-727

> Ducklow HW, Carlson CA (1992) Oceanic bacterial production. Adv Microb Ecol 12:113-181

> Franco-Vidal L, Moran XAG (2011) Relationships between coastal bacterioplankton growth rates and biomass production: comparison of leucine and thymidine uptake with single-cell physiological characteristics. Microb Ecol 61:328-341

> Fuhrman JA, Azam F (1982) Thymidine incorporation as a measure of heterotrophic bacterioplankton production in marine surface waters: evaluation and field results. Mar Biol 66:109-120

Gasol JM, Doval MD, Pinhassi J, Calderón-Paz JI, GuixaBoixareu N, Vaqué D, Pedrós-Alió C (1998) Diel variations in bacterial heterotrophic activity and growth in the northwestern Mediterranean Sea. Mar Ecol Prog Ser 164:107-124

Gasol JM, Pinhassi J, Alonso-Sáez L, Ducklow H and others (2008) Towards a better understanding of microbial carbon flux in the sea. Aquat Microb Ecol 53:21-38

Hoppe HG, Gocke K, Koppe R, Kraus G (2006) Changing bacterioplankton growth characteristics on a large spatial scale: oligotrophic versus mesotrophic ocean. Mar Ecol Prog Ser 323:21-33

ISO (International Organization for Standardization) (1997) Water analysis - Guidelines for the determination of total organic carbon (TOC) and dissolved organic carbon (DOC). ISO EN 1484. ISO, Geneva

Jørgensen NOG (1992) Incorporation of $\left[{ }^{3} \mathrm{H}\right]$ leucine and $\left[{ }^{3} \mathrm{H}\right]$ valine into protein of fresh-water bacteria: field applications. Appl Environ Microbiol 58:3647-3653

- Kirchman D, Knees E, Hodson R (1985) Leucine incorporation and its potential as a measure of protein synthesis by bacteria in natural aquatic systems. Appl Environ Microbiol 49:599-607

Kisand V, Nõges T, Zingel P (1998) Diel dynamics of bacterioplankton activity in eutrophic shallow Lake Võrtsjärv, Estonia. Hydrobiologia 380:93-102

> Kuipers B, van Noort GJ, Vosjan J, Herndl GJ (2000) Diel periodicity of bacterioplankton in the euphotic zone of the sub-tropical Atlantic Ocean. Mar Ecol Prog Ser 201: $13-25$

Lindell MJ, Granéli HW, Tranvik LJ (1996) Effects of sunlight on bacterial growth in lakes of different humic content. Aquat Microb Ecol 11:135-141

Longnecker K, Sherr BF, Sherr EB (2006) Variation in cellspecific rates of leucine and thymidine incorporation by marine bacteria with high and with low nucleic acid content off the Oregon coast. Aquat Microb Ecol 43:113-125

> Lovell CR, Konopka A (1985) Seasonal bacterial production in a dimictic lake as measured by increases in cell numbers and thymidine incorporation. Appl Environ Microbiol 49:492-500

- McDonough RJ, Sanders RW, Porter KG, Kirchman DL (1986) Depth distribution of bacterial production in a stratified lake with an anoxic hypolimnion. Appl Environ Microbiol 52:992-1000

Miracle MR, Sahuquillo M (2002) Changes of life-history traits and size in Daphnia magna during a clear-water phase in a hypertrophic lagoon (Albufera of Valencia, Spain). Verh Int Verein Limnol 28:1203-1208

> Morán XA, Massana R, Gasol JM (2001) Light conditions affect the measurement of oceanic bacterial production via leucine uptake. Appl Environ Microbiol 67:3795-3801 
Pedrós-Alió C, Brock TD (1982) Assessing biomass and production of bacteria in eutrophic Lake Mendota, Wisconsin. Appl Environ Microbiol 44:203-218

Petit M, Servais P, Lavandier P (1999) Bacterial production measured by leucine and thymidine incorporation rates in French lakes. Freshw Biol 42:513-524

Petrucio M, Barbosa F (2004) Diel variations of phytoplankton and bacterioplankton production rates in four tropical lakes in the middle Rio Doce basin (southeastern Brazil). Hydrobiologia 513:71-76

Porter KG, Feig YS (1980) The use of DAPI for identifying and counting aquatic microflora. Limnol Oceanogr 25: 943-948

Riemann B, Bell RT (1990) Advances in estimating bacterial biomass and growth in aquatic systems. Arch Hydrobiol 118:385-402

Riemann B, Søndergaard M (1984) Measurements of diel rates of bacterial secondary production in aquatic environments. Appl Environ Microbiol 47:632-638

Robarts RD, Arts MT, Evans MS, Waiser MJ (1994) The coupling of heterotrophic bacterial and phytoplankton production in a hypertrophic, shallow prairie lake. Can J Fish Aquat Sci 51:2219-2226

Rochelle-Newall EJ, Torréton JP, Mari X, Pringault O (2008) Phytoplankton-bacterioplankton coupling in a subtropical South Pacific coral reef lagoon. Aquat Microb Ecol 50: 221-229

Romo S, Villena MJ, Sahuquillo M, Soria JM and others (2005) Response of a shallow Mediterranean lake to nutrient diversion: Does it follow similar patterns as in northern shallow lakes? Freshw Biol 50:1706-1717

Romo S, García-Murcia A, Villena MJ, Ballester VSA (2008) Tendencias del fitoplancton en el lago de la Albufera de Valencia e implicaciones para su ecología, gestión y recuperación. Limnetica 27:11-28

- Ruiz-González C, Gali M, Lefort T, Cardelus C, Simo R, Gasol JM (2012) Annual variability in light modulation of bacterial heterotrophic activity in surface northwestern Mediterranean waters. Limnol Oceanogr 57:1376-1388

Ruiz-González C, Simó R, Sommaruga R, Gasol JM (2013) Away from darkness: a review on the effects of solar radiation on heterotrophic bacterioplankton activity. Front Microbiol 4:131

Servais P (1992) Bacterial production measured by ${ }^{3} \mathrm{H}$-thymidine and ${ }^{3} \mathrm{H}$-leucine incorporation in various aquatic ecosystems. Arch Hydrobiol Beih Ergeb Limonol 37:73-81

Editorial responsibility: Ruben Sommaruga, Innsbruck, Austria
Shiah FK, Ducklow HW (1997) Bacterioplankton growth responses to temperature and chlorophyll variations in estuaries measured by thymidine:leucine incorporation ratio. Aquat Microb Ecol 13:151-159

Shoaf TW, Lium BW (1976) Improved extraction of chlorophyll a and b from algae using dimethylsulfoxide. Limnol Oceanogr 21:926-928

Simon M (1994) Diel variability of bacterioplankton biomass production and cell multiplication in Lake Constance. Arch Hydrobiol 190:283-302

Simon M, Azam F (1989) Protein content and protein synthesis rates of planktonic marine bacteria. Mar Ecol Prog Ser 51:201-213

Smith DC, Azam F (1992) A simple, economical method for measuring bacterial protein synthesis rates in seawater using ${ }^{3} \mathrm{H}$-leucine. Mar Microb Food Webs 6:107-114

Smits JD, Riemann B (1988) Calculation of cell production from $\left[{ }^{3} \mathrm{H}\right]$ thymidine incorporation with freshwater bacteria. Appl Environ Microbiol 54:2213-2219

Sommaruga R (1995) Microbial and classical food webs: a visit to a hypertrophic lake. FEMS Microbiol Ecol 17: $257-270$

> Sommaruga R, Psenner R (1995) Permanent presence of grazing-resistant bacteria in a hypertrophic lake. Appl Environ Microbiol 61:3457-3459

Sommaruga R, Robarts RD (1997) The significance of autotrophic and heterotrophic picoplankton in hypertrophic ecosystems. FEMS Microbiol Ecol 24:187-200

Tammert H, Kisand V, Noges T (2005) Bacterioplankton abundance and activity in a small hypertrophic stratified lake. Hydrobiologia 547:83-90

Tibbles BJ (1996) Effects of temperature on the incorporation of leucine and thymidine by bacterioplankton and bacterial isolates. Aquat Microb Ecol 11:239-250

Torréton JP, Bouvy M, Arfi R (1994) Diel fluctuations of bacterial abundance and productivity in a shallow eutrophic tropical lagoon. Arch Hydrobiol 131:79-92

Vicente E, Miracle M (1992) The coastal lagoon Albufera de Valencia: an ecosystem under stress. Limnetica 8:87-100

Wetzel RG, Rich PH, Miller MC, Allen HL (1972) Metabolism of dissolved and particulate detrital carbon in a temperate hard-water lake. Mem Ist Ital Idrobiol 29(Suppl): 185-243

Winter C, Herndl G, Weinbauer MG (2004) Diel cycles in viral infection of bacterioplankton in the North Sea. Aquat Microb Ecol 35:207-216

Submitted: November 18, 2013; Accepted: April 21, 2014 Proofs received from author(s): June 30, 2014 